\title{
Investigating the Dynamic Interaction between Military Spending and
}

\section{Economic Growth ${ }^{\circ}$}

E. Desli ${ }^{a^{*}}$, A. Gkoulgkoutsika ${ }^{b}$ and C. Katrakilidis ${ }^{c}$

April 4, 2016

\begin{abstract}
${ }^{\circ}$ We would like to thank the two anonymous referees for their comments and suggestions. All remaining errors are our own.

a, b, c School of Economics, Aristotle University of Thessaloniki, 54124, Greece

*Corresponding author, email: desli@econ.auth.gr
\end{abstract}

\begin{abstract}
The relationship and interaction of military spending and economic growth have been theoretically and empirically investigated since the 1970 s but is still cannot provide conclusive evidence towards the direction and the quantification of the impact between the two magnitudes. The use of different data sets in terms of time periods, and number and geographic location of countries, different theoretical background leading to different econometric specifications, and single type of econometric methodology make any comparison impossible. This paper looks into the dynamic interaction between military spending and economic growth during the period 1988-2013 that includes the recent years of economic crisis covering 138 countries without making any prior assumptions about the theoretical channels of influence, whilst not limited to a single estimation method but employing a wide range of methodologies in order to form a complete picture of the long- and short-run interaction. Furthermore, as such interaction might not be linear, we create three groups of countries based on the countries' income developmental stage. Overall we find no evidence of long- and short-run causality from the military spending to economic growth except for the developing countries (positive in the long-run). However, from economic growth to military spending we find positive impact for all groups except the least developed countries. We also notice the interaction was more prominent prior to the start of the economic crisis.
\end{abstract}

JEL classification: C33; H56; O40; 057

Keywords: Military/Defence Spending; Economic Growth; Panel Co-integration; Error Correction Model 


\section{Introduction}

Military spending has been steadily reducing over the last decades from a worldwide country average closer to $4 \%$ of GDP in the 1980 s to $2.3 \%$ of GDP in 2013 but it still consumes a significant share of global resources with the overall level of military spending being close to 1.7 trillion U.S. dollars (in constant 2005 prices). 2013 was the first year to experience a military spending reduction (of $2.4 \%$ ) since 1998. Overall, during the years after the cold-war ended military spending was decreasing but it literally doubled since 1998. The increase was particularly pronounced among larger economies, both developing and developed, with the lion's share belonging to the developed countries (69\% of the total military spending in 1990, $87 \%$ in 2000 and $91 \%$ or more since 2006) and the U.S. leading the way (around 35\% of the total military expenditure). The developing countries spend well over $3.5 \%$ of their GDP in military related expenses and at the same time the least developed countries on the average are reducing this type of spending to below $2 \%$ as percentage of their GDP especially after the start of the economic crisis. The level of military spending is influenced by international factors and events, like foreign policy objectives, exogenous real or perceived threats, armed conflict or military alliances and policies to contribute to multilateral peacekeeping operation as well as domestic reasons. The decision to authorise spending for national defence is the result of the central government's allocation process of public spending among competing objectives that are served by the government. Hence, military spending is expected to influence a country's economic growth via a variety of channels. On one hand, the military expenditure is frequently viewed as unproductive public expenditure or 'crowding-out' other public spending that are considered more effectively contributing to economic development or competing with civilian activities for labour, capital and other production related resources and subsequently distorting the demand and the resulting market price for them, and hence, it is expected to undermine economic growth. On the other hand, military spending could promote economic growth by stimulating aggregate demand for goods and services and reducing excess capacity ('military Keynesianism'), or through 'spillover effects' from military research and development (R\&D) of technologically advanced products to civilian spin-off products.

The literature on the interaction of military spending and economic growth dates back in the 1970s with the Benoit Hypothesis (Benoit, 1973, 1978), that military spending stimulates the economic growth rate, being tested numerous times. However, the empirical results since then have been inconclusive and rather confusing with the interaction between military spending and economic growth and the direction of the influence between these magnitudes being one-way or mutual, positive or negative or absent depending on the set of countries under study, the sample period, the theoretical channels linking these two magnitudes and/or the applied econometric 
methodology. A great number of studies use cross sectional country based data and hence ignore the impact of time which might result to biased outcomes as well as their contribution is limited to the historic length of the sample period. The remaining majority of studies focuses on a specific country or a pair of countries or a narrow geographic area with preference to developing countries and thus they cannot be compared as they refer not only to different countries but also to frequently different time periods. Therefore, most of the existing studies have limited universal application with even more time-limited relevance. A few recent papers have used more broad data sets and applied panel data estimation techniques (Kollias et al., 2007; Chang et al., 2011; Chen et al., 2014) contributing significantly to the debate but also adding some contradictory results (e.g. Chang et al. (2011) find that there is a negative influence from military spending to economic growth whilst Chen et al. (2014) find no causality for the European region) and in general not producing comparable results due to either the investigation of different set of countries in their data samples and/or the use a different econometric specifications and estimation techniques. Furthermore, the time periods in these papers do not capture the most recent years of the economic downturn. The inclusion of the most recent time period in the analysis becomes more significant as the prevailing view over the last decade is that there is high opportunity cost in the military spending especially for the hardest hit countries by the financial crisis. Additionally, the vast majority of the studies that look to more than a pair or a small group of countries look only on the causality of military spending on the economic growth and ignore that a reverse relationship might also hold. Finally, the comparison of the findings might be not be feasible due to the use of different data sources and different definitions of military spending.

The question of interest in this paper is whether and to what extent the military spending dynamically interacts with the economic growth on a global scale without any prior assumption about the channels of such interaction that might affect our findings. We employ a worldwide sample of 138 countries covering the period 1988-2013 including the recent years of the global economic turmoil that might have changed the priorities in government spending. In order to obtain a clear and complete picture of the dynamics of such relationship over time we research both the long-run and short-run bi-directional causality. We investigate whether a long-run relationship exists using a wide range of panel co-integration methodologies for robustness including quantifying the impact where possible using the standard Dynamic Ordinary Least Square (DOLS) estimation technique, the Fully Modified Ordinary Least Square (FMOLS) and the Pesaran (1999) pooled mean group estimation (PMG). Unlike the vast majority of the literature that investigate only the direction of influence from military spending to economic growth, we research the reverse interaction as economic growth might influence the decision to finance military spending, which will serve a 
country's foreign policy targets and defence needs. We also look into the short-run causality in both directions using Granger causality tests along with the PMG methodology. Additionally, as the relationship between economic growth and military spending might not be linear (Barro, 1990) due to income developmental stage potentially influencing the outcome of the analysis, we repeat the above investigation for developed, developing and least developed group of countries following the World Bank classification (WDI, 2015). Finally, we repeat the above analysis for the 1988-2006 period, as this time span is closer to the period that is researched in the recent literature and it allows us to have a more complete view for this time interval as well to detect any changes that might have been introduced by the recent economic crisis.

The paper continues with a brief review of the related literature in section 2 , followed by a description of our model, data and the estimation methodologies employed in this paper in section 3. Next, in section 4 we present the empirical evidence of our analysis and finally, the implications and main conclusions are presented in section 5.

\section{Literature Review}

The mutual influence between military expenditure and economic growth has received considerable empirical attention, and while their relation is far from established, our knowledge about this interaction is becoming more extensive. During the period 1969-1981, that was characterised by a more relaxed tension relative to the previous years in the global power confrontation arena, the military expenditure increased by $2.9 \%$ for members in the Warsaw Pact and by $0.5 \%$ for OECD countries whilst by $11.2 \%$ for developing countries (Looney, 1988). Hence, the initial question in the literature was whether public spending in the defence area has a positive impact on the economic growth especially for the developing and less-developed countries. The first notable attempt to investigate this was the work by Benoit $(1973,1978)$, which found a positive impact of defence spending on economic growth for a group of less-developed countries and was later referred as the 'Benoit Hypothesis'. However, the applied econometric techniques were not satisfactory and that spurred an extensive interest on the area. Most of the studies that followed focused on studying the 1960s and 1970s and in general they found that the military spending was more beneficial for the richest countries with no significant impact as the per capita income was reduced and even negative impact for the less privileged countries (Feder, 1983; Frederiksen and Looney, 1982; Lim, 1983; Biswas and Ram, 1986) but the results did not hold if other factors are taken into account (Deger and Smith, 1983; Faini et al., 1984; Deger, 1986; Joerding, 1986). 
Subsequent studies that used more years in their sample offered a diversity of findings whilst the assumed channels of influence between military spending and economic growth and the assumed underlying school of thought (neoclassical, keynesian, institutionalist, marxist) steered the outcome of the studies. The neoclassical approach sees the military spending as a public good and the economic effects of the military expenditure will be determined by its opportunity cost and the effectiveness of spending on alternative causes. The keynesian approach views military spending as one aspect of state spending that increases output through multiplier effects in the presence of ineffective aggregate demand. The Institutionalist approach combines the keynesian perspective with the viewpoint of military spending spurring industrial inefficiencies as well as maintaining a powerful interest group composed of individuals, firms and organisations who benefit from defence spending regardless of the country's actual needs. Finally, the marxist approach sees the role of military spending as necessary in capitalist development and prevention of stagnation, whilst it is considered a wasteful way for lack of creating any further output in the society and for enhancing class struggle through the presence of the interest group mentioned by the institutionalists. Positive effects of military expenditure on economic growth through human capital accumulation or spin-off technologies was found by Weede (1983), Deger and Sen (1983), Deger (1986), and Yakovlev (2007), whilst through the process of enhancing infrastructure, promoting full employment, and increasing a Keynesian-type aggregate demand was found by Kennedy (1983), DeGrasse (1983), and Mueller and Atesoglu (1993). Negative effects of military expenditure on economic growth were found when alternative channels were investigated like through reducing the savings rate, crowding out investment in new capital stock, health and education and increasing tax burden with greater impact on resource restraint countries (see e.g., Smith, 1980; Cappelen et al., 1984; Mintz and Huang (1990, 1991), and Ward and Davis (1992), Batchelor et al., 2000; Dunne et al., 2001). Finally, there is another group of studies that imply that there is no relationship between the two variables mainly when the military expenditures are low (see e.g. Alexander, 1990; Kinsella, 1990; Payne and Ross, 1992; Ward et al., 1992; DeRouen, 1994; Pierroni, 2009; Dritsakis, 2004). It should be noted that almost all articles were researching only the influence of military spending on economic growth and not the potential reverse causality.

As Mitz and Stevenson (1995) first argued, the diversity of results is mainly due to the use of alternative channels of interaction between the two magnitudes, and the research methodology. On that front, there are studies that focus on one country (e.g. d' Agostino et al. (2011) and Kollias and Paleologou (2013) studied the U.S.) or a small group of countries (e.g. Dritsakis (2004) studied Greece and Turkey; Abu-Bader and Abu-Qarn (2003) reviewed Egypt, Israel and Syria), or a certain geographical region with homogeneous countries (e.g. Dunne and Mohammed (1995) selected 13 
Sub-Saharan countries; Landau (1996) focused on 17 wealthy OECD countries; Dakurah H. et al. (2000) investigated 62 developing countries; Wijeweera and Webb (2011) looked into the case of South Asia). Additionally, the vast majority of studies use cross country-sectional data that limits the validity of the findings to the period under study as well as they might introduce bias due to the heterogeneity of the countries when the sample contains diverse type of countries. The studies that used time series models have also problems with low power of estimation as the data time span was rather small. The first study to avoid these problems and utilize panel data was by Mitz and Stevenson (1995) who found that military expenditure leads to positive economic growth in less than $10 \%$ of the 103 countries in their sample. However, only a small volume of the recent literature has been using panel data: Ram (2003) used a sample of 119 countries, Yildirim et al. (2005) focused on Middle Eastern countries, Kollias C. et al. (2007) investigated 15 EU members, Chang $\mathrm{H}$. et al. (2011) utilized a dataset of 90 countries, Chen et al. (2014) analyzed 137 countries. To make matters more complicated, the time span used in the various studies is not the same, whilst frequently the cold war era is blended with more recent data. Furthermore, all analyses stop before the recent economic crisis. Finally, most of the literature constructs and estimates a regression type model with the economic growth as the dependent variable and the military expenses as an explanatory variable, or very few investigate the bi-directional relationship either by studying each direction separately or by creating a system of equations, including a second equation with the military expenses as the dependent variable and the economic growth as an explanatory variable. Thus, they focus on the long run relationship but with a limited specification. Moreover, there have been only a few studies that look into the short run relationship using Granger causality tests (e.g. Joerding, 1986; Dunne and Perlo-Freeman, 2003; Chang et. al., 2011) but they have been criticized for their contribution being limited to the period under study as well as for difficulty in interpreting their results as they were not connected with any theory. Finally, there have been arguments about the non-linearity of the relationship between the two magnitudes, but the complexity of these models did not make them popular among researchers and when they were applied they focused on a small number of states (eg. Barro, 1990; Cuaresma and Reitschuler, 2004).

As it is not possible to cover all areas of the extensive existing literature, more thorough militarygrowth literature surveys and be found in Ram (2003), Dunne and Uye (2010) and Dunne and Tian (2013). Dunne and Tian (2013) cover almost 170 studies and they argue that the more recent studies that are focusing in the post-cold war era provide stronger evidence of a negative effect of military expenditure on economic growth with the developing countries to benefit the most if their military expenditure is reduced. More specifically they state that $53 \%$ of the post-cold war cross-country studies find negative relationship, $19 \%$ positive relationship and $28 \%$ have unclear results whilst the 
vast majority of the case studies find positive impact when conflict pairs like Greece-Turkey and India-Pakistan are in focus. Finally, according to the meta-analysis by Awaworyi and Yew (2014) when positive effects of military expenditure on growth are present, they are more pronounced for developed countries than less developed countries. However, one should be cautious when studies' findings are aggregated as some countries and geographic areas are more popular than others for reasons of data availability and potential conflicts. Overall, as it can been seen from the above discussion the divergence of the time span and the selected countries in the data samples, the underlying assumptions about the channels of influence between military spending and economic growth that result to different econometric specifications as well as the variety and sometimes inadequate estimation methodology does not provide us with a clear picture of their interaction.

\section{Data, Model and Estimation Methodology}

The aim of this study is to provide a clear picture of the dynamic interaction between the military expenditure and economic growth and the direction of this interaction on a worldwide basis whilst looking into both their long-run and short-run relationship without being limited to one type of econometric specification and without adopting any a priori hypothesis on the theoretical background of such relationship.

One of the main reasons behind the adverse findings regarding the relationship between military spending and economic growth in the existing literature is the frequently limited selection of countries as well as the time span of the sample. In this study we use data for 138 countries for the period 1988-2013, which were extracted from the World Development Index (WDI, 2015) of the World Bank. The data sample contains all countries with available data that they also represent $93 \%$ of the measured worldwide GDP providing us with an almost worldwide coverage. The time period of the sample covers the post-cold war era that contains over 26 years of information since the thawing of cold war including the more recent years of economic crisis. As none of the existing studies research beyond 2006 and the economic crisis forced the hardest hit countries by the crisis to cut their government spending including their military spending, it becomes important to look into the potential impact of the economic crisis. Also, the use of panel data allows us to control for country specific effects and to incorporate such information over time. Military spending was constructed as the logarithm of the per capita Military Expenditure (MSP), whilst economic growth is the logarithm of the per capita Gross Domestic Product (GDP) both in 2005 constant U.S. dollars.

The use of a large number of countries introduces heterogeneity in the model as according to Barro (1990) the relationship between defence expenditure and economic growth may be non-linear 
(most probably U-shaped) with different levels of income influencing the causality between the two magnitudes. To alleviate this problem, we divide our countries into three smaller panels groups based on their income development level based on the World Bank classification: Developed (51 countries), Developing (59 countries), and Least Developed (28 countries). Table 1 displays the list of countries in each group.

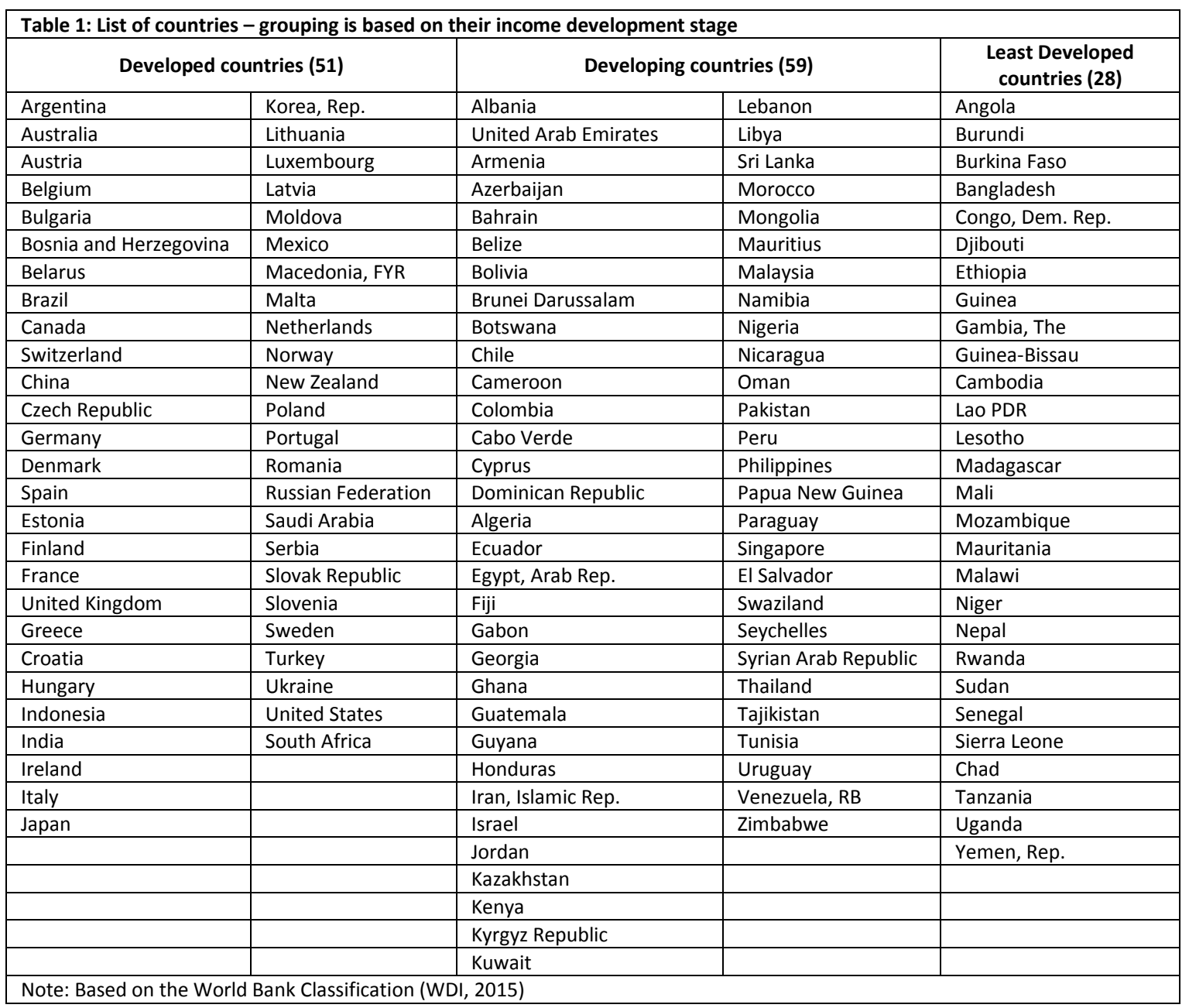

Additionally, as the existing literature indicates, the underlying assumptions about the channels of influence between military spending and economic growth determine the econometric specification and thus guide the expected outcome. Since there is no standard framework into which the empirical work can be based, we make no such prior assumptions and we will interpret ex post our findings association with these theories. Furthermore, all previous studies with a large number of countries that reach into the 2000s look into only one type of relationship, namely either the long-run or the short-run and hence their results have difficulty to be interpreted.

Prior to any analysis, we perform the necessary step to identify the integration properties of our series. For robustness we use three panel data unit root tests, which cover both the individual and the common unit root identification: (i) Breitung (2000) unit root test that applies a common unit 
root test to the entire panel data sample after removing the autoregressive part and transforming and detrending the standardised proxies, (ii) Im, Pesaran and Shin (2003) unit root test that investigates the individual Augmented Dickey Fuller (ADF) unit root tests prior to combining them to acquire the overall test statistics, and (iii) a Fisher-type unit root test developed by Maddala and Wu (1999) and Choi (2001) that combines the p-values from individual ADF unit root tests using Fisher's (1932) results.

Once we ensure the I(1) order of the variables, and in order to examine the existence of a longrun relationship between military spending and economic growth as well as the direction of such relationship we utilise co-integration analysis tests. As one of the limitations in the previous studies was the choice of the estimation method and not all alternative estimation techniques provide with the same outcome, we will employ a range of panel data co-integration tests with different statistical attributes for robustness and more well-defined results. Hence, the co-integration analysis comprises of five methodologies: (i) Pedroni (1999, 2004), (ii) Kao (1999), (iii) Johansen-Fisher test (Maddala and Wu, 1999), (iv) Stock and Watson (1993) also known as Dynamic Ordinary Least Squares (DOLS), (v) Fully Modified Ordinary Least Squares (FMOLS) from Pedroni (2000)). The last two methodologies can be performed only when we have clear indication from the first three tests that co-integration is present and they can provide with information on the numerical impact of one magnitude to the other. Additionally, the DOLS and FMOLS tests are estimated with constant trend to capture the common global movements. To conclude the long-run investigation we employ a Pooled Mean Group (PMG) estimation (Pesaran et al., 1999) that like the other two approaches allows for the heterogeneity of the cross sections but follows a pooled approach. For the investigation of the short-run relationship along with the direction of the relationship we use Granger Causality tests and the short-run estimators of the Pooled Mean Group (PMG) that as mentioned earlier gives us the pooled approach.

Additionally, we repeat the aforementioned analysis for the period 1998-2006, which is the period that is covered from the existing studies in order to look into whether there is a change after the economic crisis started in a consistent way with the remaining analysis.

\section{Empirical Evidence}

The main requirement prior to running any of the long-run and short-run evaluation tests is to check the stationarity of the variables as the use of non-stationary processes can lead to a spurious regression. We employed three panel unit root tests (Breitung (2000), Im, Pesaran and Shin (2003), and a Fisher-type test developed by Maddala and Wu (1999) and Choi (2001)) and from all these 
tests we can deduce that both variables are non-stationary in levels, while they become stationary when examined in first differences. Subsequently, both variables can be described as I(1). The results of the unit root tests can be found in Table $A$ in the Appendix.

The examination for the long-run relationship consists of five co-integration methodologies (Pedroni (1999, 2004), Kao (1999), Johansen-Fisher, Dynamic Ordinary Least Squares (DOLS), Fully Modified Ordinary Least Squares (FMOLS)) and the estimation of Pooled Group Mean model by Pesaran (1999) (PMG/ARDL) for robustness. Table B in the Appendix contains all analytical relevant results, whilst Tables 2, 3 and 4 give a schematic summary of the findings for the period 1988-2013. The first three co-integration tests, that are presented in Table 2, do not provide with the direction of causality but they indicate that there is co-integration for all groups of countries. The number of tests that indicate presence of co-integration out of the seven Pedroni's $(1999,2004)$ tests are given in parenthesis, but one should look carefully at which of the tests signal co-integration, as the econometric literature considers more powerful the Augmented Dickey Fuller (ADF) and the Philip Peron (PP) tests (Hlouskova and Wagner, 2007). Based on the estimated tests there is clear evidence of bidirectional causality only for the groups of developing countries and the entire sample (though the evidence for the entire sample for the direction from the military spending to economic growth is weaker), whilst there is no influence to either direction for the least developed countries. For the group of developed countries there is only influence from the economic growth to military spending. For the cases that co-integration is present, we proceed with the estimation of DOLS and FMOLS with constant trend where we find that the impact is positive and especially in the case of developing countries the impact is much stronger from the economic growth to military spending than the other way around.

\begin{tabular}{|c|l|l|l|l|}
\hline \multicolumn{2}{|l|}{ Table 2: Summary of Co-integration tests (Long run ): 1988-2013 } \\
\hline Test Type & All countries & Developed Countries & Developing Countries & $\begin{array}{l}\text { Least Developed } \\
\text { Countries }\end{array}$ \\
\hline Pedroni (1999, 2004) & MSP \& GDP: yes (4/7) & MSP \& GDP: no (3/7) & MSP \& GDP: yes (6/7) & MSP \& GDP: no (3/7) \\
\hline Kao (1999) & MSP \& GDP: yes & MSP \& GDP: yes & MSP \& GDP: yes & MSP \& GDP: yes \\
\hline \multicolumn{2}{|l|}{$\begin{array}{c}\text { Johansen-Fisher } \\
\text { Notes: (1) The parenthesis in the Pedroni's (1999, 2004) tests give the number of tests that a co-integrated relationship exists out of the } 7 \\
\text { tests. } \\
\text { (2) *,**, and *** denotes significance at 10\%, 5\%, and 1\% level respectively. }\end{array}$} & MSP \& GDP: yes \\
\hline
\end{tabular}

The numerical evaluation of the impact is reported in the parenthesis of the relevant rows in Table 3, but the reported numbers should be treated with caution; coefficients for the same group should not be compared across methods as each method has different measurement estimation 
method; however, coefficients from the same test can be compared across groups. Thus, we notice that in the direction of economic growth towards military spending the stronger impact is for the developing than for the developed countries. We also notice that when bi-directional causality is present, the impact of the economic growth to military spending is noticeably stronger than the reverse. The estimates of the PGM model indicate bi-directional influence for all groups of countries except the developing countries where only economic growth impacts the military spending.

\begin{tabular}{|c|c|c|c|c|}
\hline Test Type & All countries & Developed Countries & Developing Countries & $\begin{array}{l}\text { Least Developed } \\
\text { Countries }\end{array}$ \\
\hline DOLS & $\begin{array}{l}\mathrm{MSP} \stackrel{+}{\rightarrow} \mathrm{GDP}\left(0.06^{* * *}\right) \\
\mathrm{GDP} \stackrel{+}{\rightarrow} \mathrm{MSP}\left(0.74^{* * *}\right)\end{array}$ & $\begin{array}{l}n / a \\
\mathrm{GDP} \stackrel{+}{\rightarrow} \mathrm{MSP}\left(0.91^{* * *}\right)\end{array}$ & $\begin{array}{l}\mathrm{MSP} \stackrel{+}{\rightarrow} \mathrm{GDP}\left(0.10^{* * *}\right) \\
\mathrm{GDP} \stackrel{+}{\rightarrow} \mathrm{MSP}\left(1.02^{* * *}\right)\end{array}$ & $\begin{array}{l}n / a \\
n / a\end{array}$ \\
\hline FMOLS & $\begin{array}{l}\mathrm{MSP} \stackrel{+}{\rightarrow} \mathrm{GDP}\left(0.06^{* * *}\right) \\
\mathrm{GDP} \stackrel{+}{\rightarrow} \mathrm{MSP}\left(0.74^{* * *}\right)\end{array}$ & $\begin{array}{l}n / a \\
\mathrm{GDP} \stackrel{+}{\rightarrow} \mathrm{MSP}\left(0.72^{* * *}\right)\end{array}$ & $\begin{array}{l}\mathrm{MSP} \stackrel{+}{\rightarrow} \mathrm{GDP}\left(0.05^{* * *}\right) \\
\mathrm{GDP} \stackrel{+}{\rightarrow} \mathrm{MSP}\left(0.59^{* * *}\right)\end{array}$ & $\begin{array}{l}n / a \\
n / a\end{array}$ \\
\hline PMG & $\begin{array}{l}\mathrm{MSP} \stackrel{+}{\rightarrow} \mathrm{GDP}\left(0.51^{* * *}\right) \\
\mathrm{GDP} \stackrel{+}{\rightarrow} \mathrm{MSP}\left(0.86^{* * *}\right)\end{array}$ & $\begin{array}{l}\mathrm{MSP} \stackrel{+}{\rightarrow} \mathrm{GDP}\left(0.14^{* * *}\right) \\
\mathrm{GDP} \stackrel{+}{\rightarrow} \mathrm{MSP}\left(0.48^{* * *}\right)\end{array}$ & $\begin{array}{l}\mathrm{MSP} \stackrel{+}{\rightarrow} \mathrm{GDP}\left(0.60^{* * *}\right) \\
\mathrm{GDP} \stackrel{+}{\rightarrow} \mathrm{MSP}\left(0.47^{* * *}\right)\end{array}$ & $\begin{array}{l}\mathrm{MSP} \rightarrow \mathrm{GDP}: n o \\
\stackrel{+}{\rightarrow} \mathrm{MSP}\left(0.67^{* * *}\right)\end{array}$ \\
\hline
\end{tabular}

In the short-run analysis the Granger causality tests indicate that there is influence only from the economic growth to military spending for all groups except for the group of least developed countries where no causality is found. The PGM short-run estimation signals no causality for all directions and groups except a rather weak -though positive one- from military spending to economic growth for the entire sample with the quantified impact reported in the parenthesis of the relevant row in Table 4.

\begin{tabular}{|c|c|c|c|c|}
\hline Test Type & All countries & Developed Countries & Developing Countries & $\begin{array}{l}\text { Least Developed } \\
\text { Countries }\end{array}$ \\
\hline Granger Causality & $\begin{array}{l}\mathrm{MSP} \rightarrow \mathrm{GDP}: \text { no } \\
\mathrm{GDP} \rightarrow \mathrm{MSP}: \text { yes }\end{array}$ & $\begin{array}{l}\mathrm{MSP} \rightarrow \mathrm{GDP}: \text { no } \\
\mathrm{GDP} \rightarrow \mathrm{MSP}: \text { yes }\end{array}$ & $\begin{array}{l}\mathrm{MSP} \rightarrow \mathrm{GDP}: \text { no } \\
\text { GDP } \rightarrow \mathrm{MSP}: \text { yes }\end{array}$ & $\begin{array}{l}\mathrm{MSP} \rightarrow \mathrm{GDP}: n o \\
\mathrm{GDP} \rightarrow \mathrm{MSP}: n o\end{array}$ \\
\hline PMG & $\begin{array}{l}\mathrm{MSP} \stackrel{+}{\rightarrow} \mathrm{GDP}\left(0.03^{* * *}\right) \\
\mathrm{GDP} \rightarrow \mathrm{MSP}: n o\end{array}$ & $\begin{array}{l}\mathrm{MSP} \rightarrow \mathrm{GDP}: n o \\
\mathrm{GDP} \rightarrow \mathrm{MSP}: n o\end{array}$ & $\begin{array}{l}\mathrm{MSP} \rightarrow \mathrm{GDP}: \text { no } \\
\mathrm{GDP} \rightarrow \mathrm{MSP}: \text { no }\end{array}$ & $\begin{array}{l}\mathrm{MSP} \rightarrow \mathrm{GDP}: \text { no } \\
\mathrm{GDP} \rightarrow \mathrm{MSP}: \text { no }\end{array}$ \\
\hline
\end{tabular}

Next we repeat the previous analysis for the period of 1988-2006, which on one hand is comparable with the existing literature and on the other hand allows us to evaluate the impact of 
the recent economic crisis to the interaction between military spending and economic growth. The findings are summarised in Table 5, and in general following the Pedroni's $(1999,2004)$ and Kao's (1999) results we find evidence of bidirectional causality for all groups and not only for the developing countries as it was found earlier. Also, the quantification of this interaction (see Table 6) resulted to the impact being positive and as before the impact is much stronger from the economic growth to military spending than the other way around. We notice that when looking at the influence of military spending towards economic growth, the stronger impact is for the developing countries and the weakest is for the least developed countries. For the least developed group of countries the military spending as a percentage of GDP is steadily reducing since 2006 and that might explain the earlier finding of no causality between the two magnitudes. However, the PMG methodology finds evidence of causal effect in less cases than in the more extended time period and identifies the presence of interaction from military spending to economic growth only for the developing countries and the reverse relationship for all the other groups.

\begin{tabular}{|c|c|c|c|c|}
\hline Test Type & All countries & Developed Countries & Developing Countries & $\begin{array}{l}\text { Least Developed } \\
\text { Countries }\end{array}$ \\
\hline Pedroni $(1999,2004)$ & MSP \& GDP: yes (5/7) & MSP \& GDP: yes (4/7) & MSP \& GDP: yes (5/7) & MSP \& GDP: yes (5/7) \\
\hline Каo (1999) & MSP \& GDP: yes & MSP \& GDP: yes & MSP \& GDP: yes & MSP \& GDP: yes \\
\hline Johansen-Fisher & MSP \& GDP: $n o$ & MSP \& GDP: $n o$ & MSP \& GDP: $n o$ & MSP \& GDP: yes \\
\hline $\begin{array}{r}\text { Notes: }{ }^{(1)} \text { The parenthesis } \\
\text { (2) } *, * * \text {, and } * * * \text { d }\end{array}$ & Pedroni's $(1999,2004)$ & give the number of tes & hat a co-integrated relat & hip exists out of the $7 t$ \\
\hline
\end{tabular}

\begin{tabular}{|c|c|c|c|c|}
\hline Test Type & All countries & Developed Countries & Developing Countries & $\begin{array}{l}\text { Least Developed } \\
\text { Countries }\end{array}$ \\
\hline DOLS & $\begin{array}{l}\mathrm{MSP} \stackrel{+}{\rightarrow} \mathrm{GDP}\left(0.07^{* * *}\right) \\
\mathrm{GDP} \stackrel{+}{\rightarrow} \mathrm{MSP}\left(1.06^{* * *}\right)\end{array}$ & $\begin{array}{l}\mathrm{MSP} \stackrel{+}{\rightarrow} \mathrm{GDP}(0.12 * * *) \\
\mathrm{GDP} \stackrel{+}{\rightarrow} \mathrm{MSP}\left(0.84^{* * *}\right)\end{array}$ & $\begin{array}{l}\mathrm{MSP} \stackrel{+}{\rightarrow} \mathrm{GDP}\left(0.10^{* * *}\right) \\
\mathrm{GDP} \stackrel{+}{\rightarrow} \mathrm{MSP}\left(1.11^{* * *}\right)\end{array}$ & $\begin{array}{l}\mathrm{MSP} \stackrel{+}{\rightarrow} \mathrm{GDP}(0.04 * * *) \\
\mathrm{GDP} \stackrel{+}{\rightarrow} \mathrm{MSP}(1.09 * * *)\end{array}$ \\
\hline FMOLS & $\begin{array}{l}\mathrm{MSP} \stackrel{+}{\rightarrow} \mathrm{GDP}\left(0.05^{* * *}\right) \\
\mathrm{GDP} \stackrel{+}{\rightarrow} \mathrm{MSP}\left(0.94^{* * *}\right)\end{array}$ & $\begin{array}{l}\mathrm{MSP} \stackrel{+}{\rightarrow} \mathrm{GDP}\left(0.06^{* * *}\right) \\
\mathrm{GDP} \stackrel{+}{\rightarrow} \mathrm{MSP}\left(0.85^{* * *}\right)\end{array}$ & $\begin{array}{l}\mathrm{MSP} \stackrel{+}{\rightarrow} \mathrm{GDP}(0.10 * * *) \\
\mathrm{GDP} \stackrel{+}{\rightarrow} \mathrm{MSP}\left(0.75^{* * *}\right)\end{array}$ & $\begin{array}{l}\mathrm{MSP} \stackrel{+}{\rightarrow} \mathrm{GDP}(0.02 * * *) \\
\mathrm{GDP} \stackrel{+}{\rightarrow} \mathrm{MSP}\left(1.45^{* * *}\right)\end{array}$ \\
\hline PMG & $\begin{array}{l}\mathrm{MSP} \rightarrow \mathrm{GDP}: \text { no } \\
\mathrm{GDP} \rightarrow \mathrm{MSP}:\left(0.76^{* * *}\right)\end{array}$ & $\begin{array}{l}\mathrm{MSP} \rightarrow \mathrm{GDP}: \text { no } \\
\mathrm{GDP} \rightarrow \mathrm{MSP}:\left(0.82^{* * *}\right)\end{array}$ & $\begin{array}{l}\mathrm{MSP} \rightarrow \mathrm{GDP}:\left(0.60^{* * *}\right) \\
\mathrm{GDP} \rightarrow \mathrm{MSP}: n o\end{array}$ & $\begin{array}{l}\mathrm{MSP} \rightarrow \mathrm{GDP}: n o \\
\mathrm{GDP} \rightarrow \mathrm{MSP}:\left(1.13^{* * *}\right)\end{array}$ \\
\hline $\begin{array}{r}\text { Notes: }{ }^{(1)} *, \\
{ }^{(2))} \mathrm{N} \\
\text { num }\end{array}$ & $\begin{array}{l}\text { significance at } 10 \%, 5 \% \\
\text { results should be attemp }\end{array}$ & $\begin{array}{l}\text { d } 1 \% \text { level respectively. } \\
\text { across tests as they do no }\end{array}$ & efer to the same estimat & neasurements. The \\
\hline
\end{tabular}


In the context of the short-run analysis (see Table 7)) the Granger causality tests suggest that there is casual effect only from the economic growth to military spending for all groups except the group of the least developed countries where no causality is found, and the PGM methodology indicate no causality except in the case of developing countries from economic growth to military spending.

\begin{tabular}{|c|l|l|l|l|}
\hline \multicolumn{2}{|l|}{ Table 7: Summary of Causality tests (Short run ): 1988-2006 } \\
\hline Test Type & All countries & Developed Countries & Developing Countries & $\begin{array}{l}\text { Least Developed } \\
\text { Countries }\end{array}$ \\
\hline Granger Causality & MSP $\rightarrow$ GDP: $n o$ & MSP $\rightarrow$ GDP: $n o$ & MSP $\rightarrow$ GDP: $n o$ \\
& GDP $\rightarrow$ MSP: $y e s$ & GDP $\rightarrow$ MSP: yes & GDP $\rightarrow$ MSP: yes & MSP $\rightarrow$ GDP: no \\
\hline PMG & MSP $\rightarrow$ GDP: $n o$ & MSP $\rightarrow$ GDP: $n o$ & MSP: $n o$ \\
\hline & GDP $\rightarrow$ MSP: $n o$ & GDP $\rightarrow$ MSP: $n o$ & GDP $\rightarrow$ MSP: $\left(0.03^{* * *}\right)$ & GDP $\rightarrow$ MSP: $n o$ \\
\hline
\end{tabular}

\section{Implications and Concluding Remarks}

This paper looks into the dynamic interaction between military spending and economic growth during the period 1988-2013 that includes the recent years of economic crisis and covering 138 countries. As indicated by the existing literature, the adoption of a theoretical channel of how military spending influences economic growth will guide the econometric specification of the model and might influence the outcome and thus we avoid such prior assumptions. Additionally, we are not limited to single estimation method but we employ a wide range of tests that are applicable to this type of data set and allows us to form a complete picture of the interaction. Based on the empirical evidence in the previous section there is a variety of outcomes that spur from different methodologies that if viewed in isolation might lead to different conclusions. Therefore the variability of the results enforce our view that it is essential to look into a range of tests and draw conclusions from all of them rather than adopt one type of tests or methodology and deduce implications from them as each test is looking into other aspects of estimation issues.

In general, when we look into the period of 1988-2006, which is the period that is comparable with the most recent studies, we find no causality in the sort-run from the military spending to economic growth but there is some evidence of causality from economic growth to military spending for the groups of developed and developing countries as well as the entire group.

As the period is expanded to include the economic crisis years and thus covering the period 1988-2013, the short-run analysis results remain about the same but in the long-run only the group 
of developing countries experiences a bidirectional causality with the side of economic growth to military spending being affected by far the most. There is no interaction for the least developed countries and regarding the remaining groups the interaction is positive but only running from the economic growth towards the military spending. It is notable that during the last decade on the average the military spending as percentage of GDP is close to or below the $2 \%$ for the developed and least developed countries, whilst the developing countries have an average military spending well above $3.5 \%$ closer to $4 \%$ of GDP. Perhaps, for the military spending to have any significant impact on the economic growth of a country, it needs to be over a certain percentage of GDP. Furthermore, the economic crisis environment might have created additional needs for the society that increase the opportunity cost of military spending and hence its influence on the economic growth appears diminished.

Over the years the vast majority of the research has been focusing on the impact of military spending on economic growth and the theoretical channels of it. However, it seems that the causality is stronger the other way around. As a country's economic growth is established, more government funds become available and after the financing of other pressing needs for education, health, etc. is ensured, the government finds the monetary resources to finance and promote foreign policy targets, build defences against real or perceived threats, expand its influence via peace keeping operations and actively participate into multinational defence groups. The increase in military spending could also trigger the 'military keynesianism' mechanism, which is the most probable explanation for the positive impact of military spending on economic growth in developing countries even after the start of the economic crisis but not for the developed countries that are perceived to be more efficient. It is also possible that over time, whilst the economy enjoys positive economic growth, in the long-run the society is adjusted to the military spending by infusing some services of the military into the civilian life for example through $R \& D$, which in return fuels further economic growth. Finally, the lack of any dynamic interaction for the least developed countries once the economic crisis years are taken into sample might be due that on one hand the military spending is both low numerically and a small percentage of their GDP, and on the other hand any military spending fails to trigger the 'military keynesianism' mechanism as they usually suffer from a higher degree of inefficiency in their government spending process, which is usually influenced by a higher level of corruption, which in turn allows the presence of interest-groups composed of individuals, firms and organisations to benefit from defence spending regardless of the country's actual needs and hence overall the military spending not to be efficient and beneficial in its contribution to economic growth. 


\section{Appendix}

\begin{tabular}{|c|c|c|c|}
\hline & Breitung & $\begin{array}{c}\text { Im, Pesaran } \\
\text { and Shin }\end{array}$ & $\begin{array}{l}\text { ADF - } \\
\text { Fisher }\end{array}$ \\
\hline \multicolumn{4}{|c|}{ All countries } \\
\hline GDP & 7.616 & 0.108 & 1.428 \\
\hline MSP & 1.610 & -0.908 & -0.037 \\
\hline$\Delta \mathrm{GDP}$ & $-13.627^{* * *}$ & $-24.382 * * *$ & $-21.194 * * *$ \\
\hline$\Delta \mathrm{MSP}$ & $-11.697 * * *$ & $-29.748 * * *$ & $-29.071 * * *$ \\
\hline \multicolumn{4}{|c|}{ Developed } \\
\hline GDP & 4.282 & 1.237 & 1.746 \\
\hline MSP & 1.058 & -1.109 & 0.224 \\
\hline$\Delta \mathrm{GDP}$ & $-9.514 * * *$ & $-12.340 * * *$ & $328.391 * * *$ \\
\hline$\Delta \mathrm{MSP}$ & $-12.221 * * *$ & $-20.365 * * *$ & $575.982 * * *$ \\
\hline \multicolumn{4}{|c|}{ Developing } \\
\hline GDP & 3.097 & -1.657 & 2.192 \\
\hline MSP & 1.254 & -0.713 & -0.339 \\
\hline$\Delta \mathrm{GDP}$ & $-6.448 * * *$ & $-15.364 * * *$ & $460.233 * * *$ \\
\hline$\Delta \mathrm{MSP}$ & $-7.288 * * *$ & $-14.446 * * *$ & $538.756 * * *$ \\
\hline \multicolumn{4}{|c|}{ Least Developed } \\
\hline GDP & 7.667 & -0.343 & 66.090 \\
\hline MSP & 0.260 & 0.544 & 56.043 \\
\hline$\Delta \mathrm{GDP}$ & $-11.848 * * *$ & $-14.739 * * *$ & $286.749 * * *$ \\
\hline$\Delta \mathrm{MSP}$ & $-4.635 * * *$ & $-10.191 * * *$ & $236.063 * * *$ \\
\hline
\end{tabular}




\begin{tabular}{|c|c|c|c|c|}
\hline & All countries & Developed & Developing & Least Developed \\
\hline \multicolumn{5}{|l|}{ Pedroni's Panel Cointegration test } \\
\hline Panel v-Statistic & $7.004 * * *$ & 0.588 & $3.663 * * *$ & $2.328 * *$ \\
\hline Panel rho-Statistic & $-4.173 * * *$ & $-3.444 * * *$ & $-1.808 * *$ & 0.610 \\
\hline Panel PP-Statistic & $-5.761 * * *$ & $8.554^{* * *}$ & $-8.679 * * *$ & $-1.649 * *$ \\
\hline Panel ADF-Statistic & $-6.358 * * *$ & $-9.420 * * *$ & $-7.242 * * *$ & $-1.731 * *$ \\
\hline Group rho-Statistic & -0.094 & 0.899 & 2.874 & 2.488 \\
\hline Group PP-Statistic & $-9.689 * * *$ & $-4.877^{* * *}$ & $-2.320 * *$ & -0.063 \\
\hline Group ADF-Statistic & $-10.305^{* * *}$ & $-5.825 * * *$ & $-2.878 * * *$ & 0.486 \\
\hline \multicolumn{5}{|l|}{ Kao's Panel Co-integration Test } \\
\hline ADF & $3.190 * * *$ & $-7.437^{* * *}$ & $1.755^{* *}$ & $3.016^{* * *}$ \\
\hline \multicolumn{5}{|l|}{ Johansen Fisher Panel Cointegration Test } \\
\hline \multicolumn{5}{|c|}{ Hypothesized Number of CE(s): None } \\
\hline Fisher Stat. (from trace test) & $727.6^{* * *}$ & $250.9 * * *$ & $328.3 * * *$ & $148.4^{* * *}$ \\
\hline Fisher Stat. (from max-eigen test) & $680.7^{* * *}$ & $235.0 * * *$ & $307.1 * * *$ & $138.6 * * *$ \\
\hline \multicolumn{5}{|c|}{ Hypothesized Number of CE(s): At most 1} \\
\hline Fisher Stat. (from trace test) & 279.3 & 99.17 & 123 & 57.06 \\
\hline Fisher Stat. (from max-eigen test) & 279.3 & 99.17 & 123 & 57.06 \\
\hline \multicolumn{5}{|l|}{ Dynamic OLS Estimation Results } \\
\hline $\mathrm{GDP} \rightarrow \mathrm{MSP}$ & $\begin{array}{c}0.740 * * * \\
(0.047)\end{array}$ & $\begin{array}{c}0.906 * * * \\
(00073)\end{array}$ & $\begin{array}{c}1.022 * * * \\
(0.075)\end{array}$ & - \\
\hline $\mathrm{MSP} \rightarrow \mathrm{GDP}$ & $\begin{array}{c}0.064^{* * *} \\
(0.004)\end{array}$ & - & $\begin{array}{c}0.101 * * * \\
(0.011)\end{array}$ & - \\
\hline \multicolumn{5}{|l|}{ Fully Modified OLS Estimation Results } \\
\hline $\mathrm{GDP} \rightarrow \mathrm{MSP}$ & $\begin{array}{c}0.743 * * * \\
(0.011)\end{array}$ & $\begin{array}{c}0.718 * * * \\
(0.017)\end{array}$ & $\begin{array}{c}0.592 * * * \\
(0.0174)\end{array}$ & - \\
\hline MSP $\rightarrow$ GDP & $\begin{array}{c}0.067 * * \\
(0.014)\end{array}$ & - & $\begin{array}{c}0.054 * * \\
(0.023)\end{array}$ & - \\
\hline \multicolumn{5}{|l|}{ Pooled Mean Group / AR Distributed Lag Models } \\
\hline $\mathrm{GDP} \rightarrow \mathrm{MSP}$ & $\begin{array}{c}0.918 * * * \\
(0.057)\end{array}$ & $\begin{array}{c}0.481 * * * \\
(0.064)\end{array}$ & $\begin{array}{c}0.479 * * * \\
(0.042)\end{array}$ & $\begin{array}{c}0.672 * * * \\
(0.099)\end{array}$ \\
\hline MSP $\rightarrow$ GDP & $\begin{array}{c}0.505 * * * \\
(0.025)\end{array}$ & $\begin{array}{c}0.144 * * * \\
(0.017)\end{array}$ & $\begin{array}{c}0.597 * * * \\
(0.046)\end{array}$ & - \\
\hline
\end{tabular}




\section{References}

Abu-Bader S. and Abu-Qarn A., "Government Expenditures, Military Spending and Economic Growth: Causality Evidence from Egypt, Israel and Syria," Journal of Policy Modelling, 23 (6-7) (2003): 567-583.

Alexander, W.R.J., "The Impact of Defence Spending on Economic Growth," Defence Economics 2(1), (1990): 39-55.

Awaworyi, S. and S.L. Yew, "The Effect of Military Expenditure on Growth: An Empirical Synthesis," Monash Economics Working Papers, Monash University, Department of Economics (2014): 25-14.

Barro, R.J., "Government Spending in a Simple Model of Endogenous Growth," Journal of Political Economy 98 (1990): 103-125.

Batchelor, P, Dunne, JP \& Saal, DS, "Military Spending and Economic Growth in South Africa," Defence and Peace Economics 11(4) (2000): 553-571.

Benoit, E., "Growth and Defence in Developing Countries," Economic Development and Cultural Change," 26(2) (1978), 271-280.

Benoit, E., Defence and Economic Growth in Developing Countries, Lexington, MA: Lexington Books (1973).

Biswas, B., and R. Ram, "Military Expenditures and Economic Growth in Less Developed Countries: An Augmented Model and Further Evidence," Economic Development and Cultural Change 34 (1986): 361-372.

Cappelen, A., Gleditsch N.P., Bjerkholt, O., "Military Spending and Economic Growth in the OECD Countries," Journal of Peace Research 21(4) (1984): 361-373.

Chang, H.C., B.N. Huang, and C.W. Yang, "Military Expenditure and Economic Growth across Different Groups: A Dynamic Panel Granger-causality Approach," Economic Modelling 28 (2011): 2416-2423.

Chen P.F., C.C. Lee, and Y.B. Chiu, "The Nexus between Defense Expenditure and Economic Growth: New Global Evidence," Economic Modelling 36 (2014): 474-483.

Cuaresma, J.C. and G. Reitschuler, "A Non-linear Defence Growth Nexus? Evidence from the U.S. Economy," Defence and Peace Economics 15(1) (2004): 71-82.

d'Agostino G., Dunne J.P. and Pieroni L., "Optimal Military Spending in the US: A Time Series Analysis," Economic Modelling 28 (2011): 1068-1077

Dakurah A. H., Stephen P. D. and Sampath R. K., "Defense spending and economic growth in developing countries A causality analysis," Journal of Policy Modelling 23 (2001): 651-658

Deger, S. and R. Smith, "Military Expenditure and Growth in Less Developed Countries," Journal of Conflict Resolution 27(2) (1983): 335-353.

Deger, S. and S. Sen, "Military Expenditure, Spin-off and Economic Development," Journal of Development Economics 13(1-2) (1983): 67-83.

Deger, S., "Economic development and defence expenditure," Economic Development and Cultural Change 35 (1986): 179-196.

DeGrasse, R., Military Expansion Economic Decline: The Impact of Military Spending on U.S. Economic Performance, Armonk, NY: M. E. Sharpe (1983).

DeRouen, Jr., K.R., "Defense Spending and Economic Growth in Latin America: The Externalities Effects," International Interactions 19(3), (1994): 193-212. 
Dreze, J., "Military Expenditure and Economic Growth," pp. 377-382 in D.A. Clark, ed. The Elgar Companion to Development Studies, Cheltenham: Edward Elgar (2006).

Dritsakis N., "Defense spending and economic growth: an empirical investigation for Greece and Turkey," Journal of Policy Modeling 26(2) (2004): 26 249-264

Dunne, J. P. and N. Tian, "Military Expenditure and Economic Growth: A Survey," Economics of Peace and Security Journal 8(1) (2013): 5-11.

Dunne, J.P. and M. Uye, "Military Spending and Development" pp. 293-305 in A. Tan, ed. The Global Arms Trade: A Handbook, London: Routledge (2010).

Dunne, J.P. and S. P. Freeman, "The Demand for Military Spending in Developing Countries." International Review of Applied Economics 17(1) (2003): 23-48.

Dunne, J., E. Nikolaidou, and D. Vougas, "Defence spending and economic growth: A causal analysis for Greece and Turkey," Defence and Peace Economics 12(1) (2001): 5-26.

Faini, R., P. Annez and L. Taylor, "Defence Spending, Economic Structure and Growth: Evidence among Countries and over Time," Economic Development and Cultural Change 32(3) (1984): 487-98.

Feder, G., "On Exports and Economic Growth," Journal of Economic Development 12 (1983): 59-73.

Frederiksen, P.C. and R.E. Looney, "Defence Expenditures and Economic Growth in Developing Countries: Some Further Empirical Evidence," Journal of Economic Development 7 (1982): 113126.

Hlouskova, J. and M. Wagner, "The Performance of Panel Cointegration Methods: Results from a Large Scale Simulation Study," Institute for Advanced Studies, Vienna (2007).

Huang, C. and Mintz, A., "Defence Expenditures and Economic Growth: The Externality Effect," Defence Economics 3 (1991): 35-40.

Joerding, W, "Economic Growth and Defense Spending: Granger Causality," Journal of Development Economics 21(1) (1986): 35-40.

Kennedy, G., Defense Economics, London: Duckworth (1983).

Kinsella, D., "Defence Spending and Economic Performance in the United States: A Causal Analysis." Defence Economics 1(4) (1990): 295-309.

Kollias C. and S.M. Paleologou, "Guns, Highways and Economic Growth in the United States." Economic Modelling 30 (2013): 449-455

Kollias, C., N. Mylonidis, and S.M. Paleologou, "A Panel Data Analysis of the Nexus between Defence Spending and Growth in the European Union," Defence and Peace Economics 18 (2007): 75-85.

Landau D., "Is One of the 'Peace Dividends' Negative? Military Expenditure and Economic Growth in the Wealthy OECD Countries," The Quarterly Review of Economics and Finance 36(2) (1996): 183-195.

Lim, D., "Another Look at Growth and Defence in Less Developed Countries," Economic Development and Cultural Change 31 (1983): 377-384.

Looney, R. E., Third-World Military Expenditure and Arms Production, UK: Palgrave Macmillan (1988).

Mintz, A. and Huang, C., "Defense Expenditures, Economic Growth and the Peace Dividend", American Political Science Review 84 (1990): 1283-1293.

Mintz, A. and R.T. Stevenson., "Defense expenditures, economic growth, and the 'peace dividend'," The Journal of Conflict Resolution 39(2) (1995): 283-83. 
Mueller, M.J. and H.S. Atesoglu, "Defense Spending, Technological Change, and Economic Growth in the United States," Defence Economics 4(3) (1993): 259-69.

Payne, J.E., Ross, K.L., "Defense Spending and the Macroeconomy," Defence Economics (1992): 3(2), 161-168.

Pedroni P., "Critical Values for Cointegration Tests in Heterogeneous Panels with Multiple Regressors," Oxford Bulletin of Economics and Statistics 61 (1999): 653-670.

Pedroni P., "Fully Modified OLS for Heterogeneous Cointegrated Panels," Advances in Econometrics 15 (2000): 93-130.

Pedroni P., "Panel Cointegration; Asymptotic and Finite Sample Properties of Pooled Time series Tests, With an Application to the PPP Hypothesis," Econometric Theory 20 (2004): 597- 625.

Pesaran, M.H., Y. Shin and R. Smith, "'Pooled Mean Group Estimation of Dynamic Heterogeneous Panels," Journal of the American Statistical Association 94 (1999): 621-634.

Pieroni, L., "Military Expenditure and Economic Growth," Defence and Peace Economics 20(4) (2009): 327-339.

Ram, R., "Defence Expenditure and Economic Growth: Evidence from Recent Cross-Country Panel Data, " p 166-198 in A.F. Ott and R.J. Cebula, ed. The Elgar Companion to Public Economics: Empirical Public Economics, Cheltenham: Edward Elgar (2003).

Smith, R.P., "Military Expenditure and Investment in OECD Countries, 1954-1973," Journal of Comparative Economics 4(1) (1980): 19-32.

Ward, M.D. and D.R. Davis., "Sizing up the peace dividend: Economic growth and military spending in the United States, 1948-1996." The American Political Science Review 86(3) (1992): 748-55.

Weede, E. 1983. "Military Participation Ratios, Human Capital Formation, and Economic Growth: A Cross-national Analysis," Journal of Political and Military Sociology 11 (1983): 11-19.

Wijeweera A. and Webb M. J., "Military Spending and Economic Growth in South Asia: A Panel Data Analysis," Defence and Peace Economics 22(5) (2011): 545-554.

World Bank, World Development Indicators 2015, Washington, DC: World Bank (2015).

Yakovlev, P., "Arms Trade, Military Spending, and Economic Growth," Defence and Peace Economics 18(4) (2007): 317-17.

Yildirim J., Selami Sezgin \& Nadir Ocal, "Military Expenditure And Economic Growth In Middle Eastern Countries: A Dynamic Panel Data Analysis," Defence and Peace Economics 16(4) (2005): 283-295. 